\title{
Speaking Turkish in Belgian Primary Schools: Teacher Beliefs versus Effective Consequences
}

\author{
Orhan Ag̃ırda g̃ \\ Kathelijne Jordens** \\ Mieke Van Houtte ${ }^{* * *}$
}

\begin{abstract}
In this mixed-method study, we explore teachers' beliefs concerning the use of the Turkish language by Turkish children in Belgian primary schools, and we compare these findings with the effective consequences of language maintenance. The qualitative analyses revealed that teachers have very negative views about the use of the Turkish language, as they believe that speaking the mother tongue is detrimental to academic achievement. These adverse teacher beliefs are not only shaped by the assimilationist policy context in Belgium, but they are also (re)produced and reinforced by interactions between teachers and the Turkish middle-class. Nevertheless, the quantitative analyses with a data of 435 Turkish pupils in 48 schools have shown that there is no evidence that speaking Turkish, at home or at school, harms pupils' academic achievement. However, the negative school culture about the Turkish language causes feelings of rejection and reduces the sense of school belonging for pupils who speak Turkish more frequently at school.
\end{abstract}

\section{Keywords}

Language use, language maintenance, academic achievement, sense of school belonging, European Turks, Belgium

\footnotetext{
Assist. Prof. Dr., University of Amsterdam, Research Institute of Child Development and Education Amsterdam / The Netherlands

orhan.agirdag@gmail.com

** Ph.D. candidate, University of Leuven - Leuven / Belgium kathelijne.jordens@arts.kuleuven.be

**** Assoc. Prof. Dr., Ghent University - Ghent / Belgium mieke.vanhoutte@ugent.be
} 


\section{Introduction}

Education is a crucial institution. Academic achievement is particularly important among immigrants and other minorities as a route to upward mobility and other life chances. It also provides the requisite knowledge, values, and skills for a developed nation's workforce. However, educational systems of many western nations are severely challenged by achievement gaps between the native population and some large immigrant groups, such as the Turkish population in West-Europe (Crul and Schneider 2009). As immigrant groups are often younger than the native population and the immigrant populations are steadily growing, the future of western nations - in terms of both economic growth and social cohesion - largely depends on how well they succeed in providing educational opportunities for their ethnically-diverse people.

From the 1990's onwards, many policymakers in western countries responded to the growing level of immigration and ethnic inequalities by an assimilationist approach, and most visibly by increasing socio-political pressure on linguistic minorities to abandon their mother tongues at school (Macedo 2000, Helot and Young 2002, Agirdag 2009, Yagmur $2009,2010)$. These assimilationist policies assume that language maintenance is a hindrance for the social integration of minorities. As will be further outlined in this article, educational policies that favor monolingualism are very common in Belgium, where the Turkish minority is the largest linguistic minority group. Previous studies in Belgium have shown that the Turkish language is hardly welcomed in schools, and that teachers regard speaking Turkish mainly as a hindrance for academic success, and not as an asset (Agirdag 2010, Agirdag, Van Avermaet and Van Houtte 2013). Nevertheless, there are no studies we are aware of that explore how and why negative beliefs about the use of the Turkish language emerge and are reproduced within the school context. If advocates of multilingualism aim to transform teachers' negative opinions on pupils' mother tongue, then it is crucial to understand how and why those opinions emerge. Therefore, the first objective of this article is to explore the social interaction processes through which the adverse teacher beliefs about the Turkish language get established.

Secondly, while in Belgium there is a wide-spread assumption that speaking the mother tongue causes academic failure, there are very few empirical examinations of this assumption. Thus, the effective consequences of Turkish students' language use on academic achievement are largely unknown. Hence, the second aim of this study is to address this lacuna by 
examining the effects of speaking mother tongue (in the home context and in the school context) on the academic achievement of Turkish students.

On the other hand, while the relationship between language use and academic achievement is largely covered within the international literature (e.g. Mouw and Xie 1999, Han 2012), there are no studies we are aware of that examine the relationship between pupils' language use and their sense of school belonging. Students' sense of school belonging is defined as the extent to which students perceive themselves to be welcomed, valued, and respected by the members of the school community (Goodenow 1993). Sense of school belonging is not only very important because pupils have the right to feel well and welcomed at their schools, but it is also important because a higher sense of school belonging comes with improved academic achievement and with reduced anti-school behavior (Johnson, Crosnoe and Elder 2001, Demanet, Agirdag and Van Houtte 2012). However, in harsh assimilationist school contexts pupils' language use might be related to their sense of school belonging. That is, the exclusion of minority children's mother tongue in school contexts might cause feelings of rejection by those children who speak more frequently their mother tongue (see Cummins 2001). As such, the third goal in this study is to investigate whether Turkish children's language use/maintenance is related to their sense of school belonging.

Thus, this article provides insights about the language related experiences of ethnic Turkish children in primary schools in Belgium. First we will start with a sketch of the policy context of Belgium. Then, we provide methodological background of our data. We will start our empirical analysis by exploring evidence from the qualitative data, i.e. in-depth interviews with teachers. Then, we will look at the quantitative data, i.e. survey with pupils, to examine the effects of Turkish pupils' language use on their academic achievement, and on their sense of school belonging. We end with a discussion of our results.

\section{Turkish Minority in Flanders and The Language Policy Context}

This study was conducted in Flanders, that is, the Dutch-speaking region of Belgium. After World War II, Flanders rapidly developed into a multicultural society comprising immigrants from Southern Europe, Turkey, and North-Africa. Immigration was restricted by the government in 1973, however, the influx of immigrants continued via family reunification and matrimonial migration. Together with Moroccans, the Turkish immigrant group is the largest immigrant group (Agirdag and Van Houtte 2011). Given the language fractionalization within the Moroccan community, 
the Turkish language is the largest minority language. Turkish immigrants and their (grand)-children in Flanders are largely native speakers of Turkish. Turkish is not only transmitted within family context, but there is also a large access to Turkish media and cultural events in the Turkish language. Turkish newspapers, TV channels, movies and concerts are very common in Flanders, like in many places in West-Europe with large Turkish populations (Yagmur 2010).

In Flanders, Turkish minority students academically lag behind their native-Flemish counterparts at both the primary and secondary levels. This is true even when social class background is taken into account (Agirdag, Hermans and Van Houtte 2011). In fact, it has been reported that the degree of educational inequality in Flanders is among the highest in developed nations (OECD 2006). In other words, the academic achievement gap between Turkish immigrants and natives is a very serious concern in Flanders. Educational policy makers argue that the harsh inequalities in the Flemish education are mainly caused by the linguistic deficiencies of the immigrants. For instance, the former Flemish minister of education Frank Vandenbroucke stated that his administration has three policy priorities for creating equal opportunities in education: "language, language and language". The current Flemish minister of education, Pascal Smet, claimed that linguistic deficiencies are the main, if not the only, cause of underachievement of immigrant students (see also Agirdag 2010, Agirdag et al. 2013). While a great part of Turks in Flanders are also proficient speakers of Dutch, they are rarely referred to as 'bilingual', but rather as 'linguistically different' (In Dutch: 'anderstaligen'). This already reflects the pejorative perspective on multilingualism (see also Blommaert, Creve and Willaert 2006). The mother tongue education programs in Flanders, which were financed by the Turkish government, are mostly canceled during the 1990's. Even though Belgium has two major languages (i.e. Dutch in Flanders, and French in Wallonia), bilingual instruction does rarely occur since Belgian law only permits education in one official language. While in 1998 the French speaking region (Wallonia) enabled schools to organize bilingual education, in the Dutch speaking region (Flanders) bilingual instruction is still virtually nonexistent. In fact bilingual education in Flanders is only allowed as a scientific experiment and only few projects on this subject have been conducted (Bollen and Baten 2010). The overwhelming social and political pressure for Dutch monolingualism and the aversion to bilingual education in Flanders are related to historically deep-rooted fears against the dominance of French, and the strong presence of the right-wing Flemish-nationalist politics. For in- 
stance, the conservative Flemish nationalist party (N-VA) is presently the largest party in Flanders, and, their rising nationalism has considerably affected mainstream policies, which do not include linguistic pluralism. Along these lines, recent policies have excluded non-Dutch speakers from social housing and other social welfare programs (see Maly 2012).

\section{Methods}

\subsection{Sample and Design}

We use qualitative and quantitative data gathered as part of the Segregation in Primary Education in Flanders project. Quantitative data were collected during the academic year 2008-2009 from 2845 pupils in a sample of 68 primary schools in Flanders, of which 435 children in 48 schools were from Turkish origin (grandmothers born in Turkey or speakers of Turkish language). Multistage sampling was conducted. In the first instance, to encompass the entire range of ethnic composition, we selected three cities in Flanders that had relatively ethnically diverse populations. Second, using data gathered from the Flemish Educational Department, we chose 116 primary schools within these selected cities and asked them to participate; $54 \%$ of them agreed to. Because the nonresponse rate was not related to the ethnic composition of schools, the schools in the data set represent the entire range of ethnic composition, from those with almost no Turkish pupils to some composed of $87 \%$ Turkish children (see Table 1). In all schools that agreed to participate, our research team surveyed all the fifth-grade pupils present during our visit. If there were fewer than 30 fifth-grade pupils present, we surveyed all the sixth-grade pupils as well. Given a time limitation, we could not test all curriculum subjects, so we focused on math achievement because a large proportion of the respondents were not native speakers of Dutch, and math tests are less linguistically biased than subjects such as reading (Abedi, Hofstetter and Lord 2004).

The qualitative data were collected during the academic year 2009-2010 from five schools selected from the 68 schools just described. These five schools were intentionally selected as representative of the entire range of ethnic compositions. To reflect their ethnic composition, we use the pseudonyms White Circle, White Triangle, Black Triangle, Black Square and Black Circle to refer to these. The majority of students in the Black Square (65\%) and Black Circle (87\%) are Turkish pupils. In Black Triangle almost one third of students were Turkish (32\%). In White Triangle (2\%) and White Circle (5\%) there were only few Turkish students. 
In all five schools, the first author conducted in-depth interviews with the school principals, in addition to 4 or 5 teachers; a total of 26 respondents were interviewed. The interviews took place in the school. To ensure anonymity, we use pseudonyms for our respondents. All the teachers were native Belgians except one teacher who was immigrant Moroccan (Nadia). The age range of the teachers was 26-58, with a median age of 41 . During the interviews, teachers were asked to reflect on themselves, their profession as teachers, their schools in general, colleagues, pupils, parents, the school composition, the differences between schools, and issues of multicultural education.

In this study, we used a mixed-method approach. The qualitative analysis is based on semi-structured, in-depth interviews in which "the interviewer asks certain, major questions the same way each time, but is free to alter the sequence and to probe for more information" (Fielding 1993:136). The in-depth approach was necessary to create an informal atmosphere that would allow the respondents to speak at length with the interviewer and generate mutual trust, a process that increases the reliability of the data. The interviews were conducted in Dutch. Because of the translation into English, some nuances and typical Dutch expressions may be lost in this report. All interviews were audiotaped and transcribed. These transcriptions were analyzed with detailed reading and successive open and focused coding (Esterberg 2002). For this coding process, we used qualitative data software NVivo 9. The first author of this article was responsible for the primary coding process and the selection of the quotes to be presented in the analysis. To ensure reliability and validity, the second and the third author of this article independently reread the coding and the selected quotes. They provided feedback to the first author in case of disagreement regarding coding and interpretation of the quotes.

The quantitative data consisted of a clustered sample of pupils nested within the schools. Multilevel modeling was therefore most appropriate (SPSS 21, MIXED-procedure). But first, we calculated bivariate Pearsons correlations to assess the associations between language use, academic achievement and sense of school belonging. Secondly, to account for spurious relationships, we examine the effects of language use in a multilevelregression model on academic achievement and on sense of school. In the multilevel models, we take account of various variables that might equally have an influence on academic achievement and sense of school belonging. At student-level we control for grade, gender, generation, and parental socioeconomic status. At the school-level, we control for the percentage of 
Turkish students at school and the mean parental socioeconomic status (see Variables section). Missing values were handled with multiple imputation; five imputations were requested.

\subsection{Variables}

\subsubsection{Independent variable}

Language use. We measure the extent to which pupils' speak Turkish with seven items. Pupils indicated the degree to which they speak Dutch or another language (1) at home with father; (2) at home with mother; (3) at home with siblings; (4) in the classroom with friends; (5) at the playground with friends; (6) outside the school with friends. Each item has five possible responses ranging from 'always Dutch' (score 1) to 'always another language' (i.e. Turkish) (score 5). Based on a factor analysis with Varimax rotation, we distinguished between speaking Turkish at home (items 1, 2 and 3 loading higher than 0.72) and speaking Turkish at school (items 4, 5 and 6 loading higher than 0.60). The mean score of items 1, 2 and 3 equals 2.79 and the mean score of items 4, 5 and 6 equals 3.69. (Score 3 denotes 'equally Dutch and another language). However, in the analysis, we use the factor score instead of mean scores. We did so because factor scores take account of different item strengths in contrast with mean scores (DiStefano, Zhu and Mîndrila 2009). As shown in Table 1 , these factor scores are mean centered $($ mean $=0)$ and standardized (standard deviation $=1$ ), as such, their minimum value is negative.

\subsubsection{Dependent variables}

Academic achievement in our analysis is measured by math achievement, measured using a test developed by Dudal and Deloof (2004), which is based on standardized educational attainment levels for Flemish students in the fifth grade of their primary education. The test consists of 60 items, which cover elementary arithmetic, problem solving, fractions, decimals, and long division. Scores are calculated by using a 2-parameter Rash Model (IRT). See Table 1 for descriptive statistics.

Sense of school belonging. Sense of school belonging was measured using a Dutch translation of Goodenow's (1993) 18-item Psychological Sense of School Membership scale. Four sample items are 'The teachers here respect me', 'Sometimes I feel as if I don't belong here' (reverse coded), 'People at this school are friendly to me' and 'It is hard for pupils' like me to be accepted here' (reverse coded). There are five answer categories, ranging from absolutely do not agree (scored 1) to completely agree 
(scored 5). Scores are calculated by taking the scores of the one factor solution in factor analysis. See Table 1 for descriptive statistics.

\subsubsection{Control variables}

Grade. Our research concentrated on fifth- and sixth-grade pupils. Therefore, most of the respondents were aged 11 or 12 . Given the high correlation between age and grade (Cramer's $\mathrm{V}=0.64 ; \mathrm{p}<0.001$ ), we had to choose one of these two variables for the model. Because the sample was unbalanced in terms of grade, we opted for the grade (see Table 1).

Gender. The pupils' sample was divided equally with respect to gender, with around $46 \%$ female respondents (boy $=0$, girl $=1)($ see Table 1$)$.

Generation. We distinguished between first generation of Turkish children (born in Turkey, 10\%), second generation immigrant Turkish children (child born in Belgium, at least one parent born in Belgium, 83\%), and third generation immigrant Turkish children (child and both parents born in Belgium, 6\%).

Parental Socioeconomic Status (SES). We measure family SES of the pupils by assessing the occupational prestige of the father and mother (Erikson, Goldthorpe and Portocarero 1979). Information about the occupation of the parents was supplied by the pupils. The highest prestige occupation of the parents was used as an indicator for the SES of the family (see Table 1).

School Level: \% Turkish. We control for the percentage of Turkish children at each school. We calculated this percentage by aggregating the individual-level information on ethnic background (see Table 1).

School Level: Mean SES: We control for mean SES of school, as aggregated of individual SES values. Descriptive statistics are provided in Table 1.

Table 1. Descriptive Statistics

\begin{tabular}{lccccc}
\hline & N & Minimum & Maximum & Mean & SD \\
\hline Turkish at home & 395 & $-3,10$ & 2,67 & 0,00 & 1,00 \\
Turkish at school & 395 & $-1,66$ & 3,44 & 0,00 & 1,00 \\
Academic achievement & 429 & $-2,42$ & 1,89 & $-0,22$ & 0,84 \\
Sense of Belonging & 406 & $-3,26$ & 2,12 & 0,00 & 1,00 \\
\hline Grade & & & & & \\
\hline Fifth grade & 302 & 0 & 1 & & \\
Sixth grade & 133 & 0 & 1 & & \\
\hline
\end{tabular}




\begin{tabular}{lccccc}
\hline Gender & & & & & \\
\hline Boy & 234 & 0 & 1 & & \\
Girl & 198 & 0 & 1 & & \\
SES & 429 & 0 & 8 & 2,80 & 1,83 \\
School-level: \% Turks & 435 & 1,79 & 87,80 & 39,60 & 23,01 \\
School-level: SES composition & 435 & 1,65 & 6,71 & 3,38 & 1,05 \\
\hline
\end{tabular}

\section{Results}

\subsection{The Origins of Adverse Teacher Beliefs against Turkish}

The first objective of this study is to explore how and why negative beliefs about of the use of Turkish language emerge in school context. First of all, the results of the in-depth interviews with teachers pointed out that teachers generally perceive Turkish pupils as being different than other minority pupils such as Moroccan, Spanish and Greek pupils. That is, teachers argued that in contrast with other minority students, Turkish students tend to retain their mother tongue and speak more frequently in Turkish at school:

Katja: When I started working here, we used to have Italians, Spanish [pupils] and a lot of nationalities. Greeks [as well]. And now, it is mostly Turks and Moroccan and some Belgian [pupils]. And the difference is, back then, more Dutch was spoken, [pupils] among each other, and at the playground. Last year, I had a class and I had to say constantly: "speak Dutch, speak Dutch". Actually, only Turkish children do speak another language among each other, they speak Turkish. Other nationalities don't do that. So in the past, Dutch was here the common language. (Teacher, Black Circle, Female, 45)

Saskia: Turkish children speak Turkish among each other. But Moroccans, for instance, don't do that because there are a lot of dialects and they are less proficient in it. But Turkish children speak a lot of Turkish among each other. (Teacher, Black Square, Female, 30)

As Turkish children were regarded as the only ones who persistently speak another language than Dutch, teachers mostly referred to the Turkish language when they argued about the alleged unfavorable consequences of mother tongue retention. In the Black Circle and in the Black Square (i.e. in schools with a majority of Turkish children), teachers perceived the use of the Turkish language as the antecedent of poor proficiency in Dutch, 
and poor academic achievement, and it was regarded as the 'the big problem' with respect to academic achievement:

Researcher: What do you think is the decisive factor [regarding academic achievement]?

Sarah: Here, the language is the big problem, the language plays an important role. That is, they [the pupils] go outside and they immediately start speaking Turkish. In the hall, again Turkish, with their friends, again in Turkish, when they quickly have to tell something, again Turkish. So we are like constantly, all day long: "Speak Dutch with each other, say it in Dutch.” (Teacher, Black Square, Female, 29)

Kelly: Those children do often speak another language than Dutch, or much less [Dutch] is spoken than within a typical Flemish family. As a consequence, when they come to this school, they are not able to speak Dutch. Also in this neighborhood, [there are] Turkish shops, Turkish bakery, Turkish butchery. So they don't come in contact with Dutch. So they start with underachievement at the very beginning. (Teacher, Black Circle, Female, 26)

These negative beliefs about the use of the mother tongue were also present in schools where there are only few Turkish children. For instance, teachers form the White Circle stated that they do not have 'the problem' of speaking Turkish because Turkish pupils had very few classmates to speak Turkish with. But even under these circumstances, there was still a strict Dutch monolingualism policy and children would get addressed when they spoke another language.

Lise: The problem doesn't happen [here] that much, we don't have the issue because there are no many children who speak Turkish at school, so it's just a practical thing, there are just few or no classmates to speak with. But, very rarely, for instance when a kid gets angry, then it happens that a kid speaks another language, that [he or she] expresses itself in another language. But normally, when we hear a child speaks another language, we will address it, we will say: "at school you have to speak Dutch". But the problem does rarely or not happen here, because there are only few. (Teacher, White Circle, Female, 47)

Negative beliefs about the use of the Turkish language and other ethnic minority languages in Flemish schools are well documented in other studies as well (e.g. Jaspers 2008, Agirdag 2010). Our core question in this 
study is, however, where these persistent unfavorable teacher opinions come from. Off course, the political climate that we have described earlier in this article might have an influence on teachers' cognition. However, our findings suggest that social interactions between teachers and Turkish parents equally establish (or at least reinforce) negative thoughts about the Turkish language in school context. First, some Turkish parents communicated to the school staff that they prefer Dutch monolingualism in the school context. These parents argued that their proficiency in Turkish was not well anymore:

Saskia: Our audience [pupils at school] is so linguistically poor, we choose for [Dutch monolingualism]. And the Turkish parents they asked it themselves - they [said] could not speak Turkish well anymore, and neither Dutch, that is what Turkish parents told us, so we did choose for Dutch because they might learn Turkish at home, but at school there is just one language, so we choose to have only one language [Dutch]. (Teacher, Black Square, Female, 30)

Especially social interactions with middle-class Turkish parents reinforced monolingualism beliefs among teachers. For instance, one teacher argued that high-educated Turkish families spoke more frequently Dutch with their children than low-educated Turkish families. As such the higher academic achievement of the middle-class Turkish children was attributed to the fact that they spoke less Turkish:

Rik: [Turkish] pupils with high educated parents usually do also master the Dutch language very well. And at home they also speak Dutch all the time. They have almost the same way of living as we do and they speak Dutch and everything. While other [low educated] parents insist on speaking Turkish at home. So they have difficulties with the language at school, with the result that their academic performance is much lower than other pupils. (Teacher, Black Square, Male, 27)

Secondly, teachers' interactions with the few Turkish teachers in Belgian schools, who mostly teach Islam or used to provide mother-tongue education in the past, functioned also as a legitimization of monolingualism. That is, Turkish teachers communicated to their native Belgian colleagues that the mother tongues of Turkish speaking children were useless. These teachers were mostly educated in Turkey. And generally spoken, the middle-class from Turkey regards the Turkish language that is spoken by the working-class European Turks as degenerated and erroneous Turkish. 
Katja: The Turkish teachers that we had in the past, they said, and the Islam teacher said that as well, they [pupils] don't speak their mother tongue well. They always say, if they know their mother tongue well, than it will be easier to learn a second language. But because here it [the Turkish language] is so degenerated, it does not have a positive effect. That [positive effects] will only take place if they knew their mother tongue well. Those teachers that we used to have in the past, they taught in Turkish, they always said: it doesn't work here because they are not proficient in their mother tongue, even if they speak Turkish at home, it's is not clean Turkish, neither a dialect, but a language full of errors, wrong sentences. That does not work. (Teacher, Black Circle, Female, 45)

Thirdly, some Turkish parents avoided to enroll their children in schools such as the Black Square. They motivated their avoidance by referring to the high share of Turkish pupils at these schools, which they believe would be detrimental for the Dutch proficiency of their children:

Maria: They [parents] compare schools. Once, a Turkish father came here, and one of the questions that is always being asked is: "are there a lot of Turkish children here at school?” It was a Turkish parent. I said: "Not all of them, but yeah, most of them are Turkish". "Oh, because I want my child to learn Dutch very well". So my answer was: "sir, here we are trained to teach those children Dutch as soon as we can. But does your child already speak Dutch?" "No" ... So he found it hard to enroll his child in a school where there are a lot of Turkish children, but he [himself] never spoke Dutch to his child. I just don't get it, I can't understand that. (Principle, Black Square, Female, 30)

Similarly, some Turkish parents who decided to enroll their children in the White Circle, had communicated to the school staff that the single most important reason why they did choose for White Circle is that they want to avoid contact between their children and other Turkish speaking children. It should be noted that analysis of quantitative data (not shown here) revealed that Turkish families in the White Circe are mostly middleclass Turkish parents.

Patrick: Each year, I have [Turkish parents] who come here, and one of the reasons, most of them say: "[in other schools] there are too many, they speak Turkish in the classroom, Turkish on the playground, during the lunch, when they are in the rows, they always speak 
Turkish and we don't want that anymore. We want our children to become perfectly integrated". It might sound weird, but our most critical parents are immigrant parents. And they are right, I think, they realize how important it is for their own future to become good integrated in our culture. Because the future of those children is here, and they will have to speak Dutch in their professional life. (Principle, White Circle, Male, 45)

Koen: Here, we have little trouble with that. Because most [Turkish parents] who come to our school, those two [Turkish pupils] in the sixth grade, they came here because they didn't want to go to an innercity school because there are too many Turks and Moroccans there, and rarely Dutch is spoken. Their parents have decided themselves: "My children have to speak better Dutch because they will grow up here and later they have to work here." If they go school elsewhere, there will be a lot more Turks, and they will speak Turkish among each other and they want to avoid that. That was in fact their main reason. (Teacher, White Circle, Male, 52)

Hans: For instance, the migrant children here in this school, their folks have chosen to come to our school because here Dutch is spoken, I mean, people who want to become integrated, you know, of course it is in their benefit that their children speak Dutch well. (Teacher, White Circle, Male, 58)

As shown in previous quotes, speaking Turkish was generally believed to result in poor academic performance. As such speaking Turkish was formally forbidden in most schools. The school staff communicated their aversion toward pupils' mother tongues by strong and persistent encouragement of the exclusive use of Dutch. Moreover in most schools teachers would punish pupils for not speaking Turkish at school:

Rik: Normally, we forbid that, so it is not allowed to speak Turkish at school. But we see that when they are among each other, or when there are conflicts, that they quickly switch to the Turkish language. So we have to constantly watch over it, because even if they speak very quietly, we see that they trying to speak Turkish all the time. (Teacher, Black Square, Male, 27)

Katja: The school regulations state that only Dutch should be spoken and otherwise they [pupils] get punished. (Researcher: And what do you specifically mean by punishing?) Katja: For example I work with 
tally marks, when they have five strokes, than they have to write down a page or clean the playground. But it is dependent on the group. With some groups, I have to punish more strictly and quickly. (Teacher, Black Circle, Female, 45)

The only exception to this rule was just one teacher who had some knowledge of educational research and who talked about the benefits of bilingualism:

Simon: I know it is politically spoken not self-evident, but I truly believe, and I am convinced of the fact that if we should teach those children reading and writing in Turkish, [then] their writing and readings skills in Dutch will improve. But it doesn't happen, nowhere. But when I hear about research saying that this would the best way to do it, the best way to teach children to read and write, why don't we do that? (Black Circle, Teacher, Male, 56)

\subsection{The Effective Consequences of Language Use: Academic Achievement}

In the previous section, we focused on teachers' beliefs about language use and we demonstrated how these thoughts partly emerge through interactions with (middle-class) Turkish parents and Turkish teachers, who tend to prefer Dutch monolingualism in school context. In this second section, our aim is to examine whether the alleged negative consequences of speaking Turkish correspond with the empirical reality. In other words, the second objective of this study is to examine the effects of speaking Turkish on academic achievement of Turkish pupils. For this purpose, we first look at bivariate Pearson correlations between frequency of speaking Turkish (at home or at school) and academic achievement. We found that there was no significant association between speaking Turkish at home and academic achievement $(r=-0.047 ; p=0.33)$, and no significant association between speaking Turkish at school and academic achievement $(r=-$ $0.046 ; p=0.34$ ). The results of the multilevel regression model (as shown in Table 2), do not reveal any different results. That is, there is no significant effect of speaking Turkish at home on pupils' academic achievement $(b=0.022 ; p=0.58)$, neither is the effects of speaking Turkish at school significant $(b=-0.032 ; p=0.43)$. Hence, it seems that one of the most recurring assumptions within Belgian education is not supported by our empirical findings: there is no evidence that speaking more Turkish, at home or at school, harms students' academic achievement. 
Table 2. Multilevel regression on pupils' academic achievement

\begin{tabular}{lccc}
\hline & $\mathrm{b}$ & $\mathrm{se}$ & $\mathrm{p}$ \\
\hline Intercept & -1.233 & 0.327 & 0.00 \\
Grade (1=6th) & 0.516 & 0.086 & 0.00 \\
Gender (1= Girl) & -0.263 & 0.076 & 0.00 \\
Generation (1st) & -0.076 & 0.191 & 0.69 \\
Generation (2th) & 0.042 & 0.154 & 0.79 \\
Generation (3th) & ref. & & \\
SES & 0.058 & 0.021 & 0.01 \\
\% Turks & 0.003 & 0.003 & 0.42 \\
Mean SES & 0.201 & 0.059 & 0.00 \\
Turkish at home & 0.022 & 0.040 & 0.58 \\
Turkish at school & -0.032 & 0.041 & 0.43 \\
\hline
\end{tabular}

\subsection{The Effective Consequences of Language Use: Sense of Belonging}

Established that speaking Turkish at home or at school is not related to students' academic achievement, we will now examine whether language use is related to pupils' sense of belonging in schools, that is our third research objective. For this purpose, we first examine the bivariate Pearson correlations between frequency of speaking Turkish in home context and pupils' sense of school belonging, and then between frequency of speaking Turkish in school context and pupils' sense of belonging. We found that there was no significant association between speaking Turkish at home and sense of school belonging $(r=-0.041 ; p=0.38)$. However, there is a significant negative association between speaking Turkish at school and sense of school belonging $(r=-0.129 ; p=0.01)$. The coefficients of the multilevel regression model (as shown in Table 3) reveal a similar result. The effect of speaking Turkish at home on sense of belonging is insignificant $(b=-0.073 ; p=0.15)$, while speaking Turkish at school is significantly related to pupils' sense of belonging $(b=-0.155 ; p=0.01)$. Hence, it seems that Turkish pupils who speak their mother tongue more frequently at school feel less belonging or less welcomed in their schools. 
Table 3. Multilevel regression on pupils' sense of school belonging

\begin{tabular}{lccc}
\hline & $\mathrm{b}$ & $\mathrm{se}$ & $\mathrm{p}$ \\
\hline Intercept & -0.030 & 0.344 & 0.93 \\
Grade (1=6th) & 0.114 & 0.108 & 0.29 \\
Gender (1= Girl) & 0.010 & 0.097 & 0.92 \\
Generation (1st) & 0.298 & 0.254 & 0.24 \\
Generation (2th) & 0.202 & 0.203 & 0.32 \\
Generation (3th) & ref. & & \\
SES & -0.013 & 0.027 & 0.63 \\
\% Turks & 0.002 & 0.003 & 0.55 \\
Mean SES & -0.071 & 0.060 & 0.24 \\
Turkish at home & -0.073 & 0.051 & 0.15 \\
Turkish at school & -0.155 & 0.055 & 0.01 \\
\hline
\end{tabular}

\section{Conclusion and Discussion}

The purpose of this study was to provide insights about teachers' beliefs concerning language use of Turkish pupils in Belgian (Flemish) primary schools, and to compare these findings with the effective consequences of language use. Using both qualitative and quantitative techniques, we examined three research questions. Our first research question focused on how the persistent negative opinions about the use of the Turkish language are reproduced within the Flemish education. The results of the indepth interviews revealed that teachers perceive Turkish pupils as being different than other minority students: teachers stated that in contrast with other ethnic minorities, Turkish pupils do speak more often their mother tongue among each other. We also found that teachers in schools with high share of Turkish students regard the use of Turkish as the single most important problem of their schools, as they believed that mother tongue retention was detrimental for academic achievement. Teachers in schools with few Turkish students noted that they do not have 'the problem', but still imposed strict Dutch monolingualism. Most importantly, we found that these negative beliefs might not only be influenced by the policy context in Flanders (that very much favors assimilation and Dutch monolingualism), but also that social interactions between Flemish teachers and the Turkish middle-class reinforce negative thoughts about the use of the Turkish language. This happened at least in four different ways. 
First, the middle-class Turkish parents avoided schools with high share of Turkish pupils, and they chose to enroll their children in school with very few Turkish children to rule out that their children will speak their mother tongue in school. Second, some Turkish parents requested to the staff in schools with high share of Turkish pupils to only allow Dutch at school. Third, some teachers argued that middle-class Turkish parents spoke more often Dutch with their children, and consequently teachers attributed the educational success of Turkish middle-class children to their language choice. Fourth, Turkish teachers communicated to Flemish teachers that the mother tongue proficiency of Turkish children were rather limited, erroneous and unclean Turkish. In fact, these four examples are clear illustrations of what Pierre Bourdieu calls 'symbolic violence' (1991). That is, Bourdieu (1991) argues that social dominance can only persist because the dominant groups in society impose their judgments, such as beliefs about monolingualism, upon dominated groups, such as the bilingual Turkish community. Once the dominated groups internalize the point of view of the dominant, they will defend it as if it was a universal point of view, even when these judgments are completely against their own interests.

However, one might argue that teachers' beliefs about the detrimental consequences of language use might be accurate. It is very common to think that speaking more frequently Turkish cause poor academic achievement. Therefore, as part of our third research question, we tested this hypothesis by means of quantitative analyses. Using a factor analysis, we distinguished between language use at home and at school. Both the bivariate models and the multivariate (multilevel) models pointed out that the extent of speaking Turkish - at home or at school - was not significantly related to pupils' academic achievement. Hence, one of the most recurring assumptions within the Flemish educational system (i.e. about the detrimental effects of speaking) is not supported by our data.

The fact that language maintenance and academic achievement are unrelated does not mean that language use is completely irrelevant. That is, as part of the third research question, we examined the effects of language use on pupils' sense of school belonging. The bivariate and multivariate (multilevel) analysis revealed that there is negative relationship between Turkish pupils' mother tongue use at school and their sense of school belonging. In other words, pupils' who spoke more frequent their mother tongue at school feel less belonging or less welcomed in their schools. This result is hardly surprising, given the very negative school climate about their language background: Turkish pupils' are constantly addressed to 
speak only Dutch and they are also punished for speaking their mother tongue. But when Turkish pupils have to leave their mother tongues behind at the school gates, they also leave a part of their identities outside the school. Consequently, they have less emotional connection to the school: they feel less respected, less welcomed or less belonging to school.

This article provides a good amount of ammunition for civil society organizations and activists that support multilingualism. Our results imply that supporters of multilingualism should not only address policymakers, but as the negative opinions about the use of the Turkish language are also shared by the Turkish middle-class, it might also be necessary to address the European Turkish community about the assets of language maintenance, for instance by pointing at potential economic benefits of language maintenance (see Agirdag 2014). While doing this, it might also be helpful to note that speaking Turkish at home or at school does not negatively affect achievement, as clearly shown in this study. Finally, advocates of multilingualism might address educators and school staff by referring to the potential detrimental consequences of monolingualism on pupils' sense of school belonging. In the end, a school environment that triggers feelings of rejection, instead of feelings of belonging, cannot and should not be considered an effective learning environment.

\section{References}

Abedi, Jamal, Carlyn H. Hofstetter and Carol Lord (2004). "Assessment Accommodations for English Language Learners: Implications for Policy-Based Empirical Research". Review of Educational Research 74 (1): 1-28.

Agirdag, Orhan (2009). "All Languages Welcomed Here”. Educational Leadership 66 (7): 20-25.

(2010). "Exploring Bilingualism in a Monolingual School System: Insights from Turkish and Native Students from Belgian Schools". British Journal of Sociology of Education 31 (3): 307-321.

, (2014). "The Long-Term Effects of Bilingualism on Children of Immigration:

Student Bilingualism and Future Earnings". International Journal of Bilingual Education and Bilingualism 17 (4): 449-464.

Agirdag, Orhan, Maarten Hermans and Mieke van Houtte (2011). "The Association between Islamic Religion, Religiosity and Academic Achievement". Pedagogische Studiën 88 (5): 339-353. 
Agirdag, Orhan, Piet Van Avermaet and Mieke van Houtte (2013). "School Segregation and Math Achievement: A Mixed-Method Study on the Role of Self-Fulfilling Prophecies”. Teachers College Record 115 (3): 1-50.

Agirdag, Orhan and Mieke van Houtte (2011). "A Tale of Two Cities Bridging Families and Schools”. Educational Leadership 68 (8): 42-46.

Blommaert, Jan, L. Creve and Evita Willaert (2006). "On Being Declared Illiterate: Language-Ideological Disqualification in Dutch Classes for Immigrants in Belgium”. Language \& Communication 26 (1): 34-54.

Bollen, Katrien and Kristof Baten (2010). "Bilingual Education in Flanders: Policy and Press Debate (1999-2006)". Modern Language Journal 94 (3): 412-433.

Bourdieu, Pierre (1991). Language and Symbolic Power. Cambridge, Mass.: Harvard University Press.

Crul, Maurice and Jens Schneider (2009). "Children of Turkish Immigrants in Germany and the Netherlands: The Impact of Differences in Vocational and Academic Tracking Systems”. Teachers College Record 111 (6): 1508-1527.

Cummins, Jim (2001). “Bilingual Children's Mother Tongue: Why Is It Important for Education?”. Sprogforum 19: 15-20.

Demanet, Jannick, Orhan Agirdag and van Houtte, Mieke (2012). "Constrict in the School Context. The Impact of Etnic School Diversity on the Quantity and Quality of Friendships". The Sociological Quarterly 53 (4): 654-675.

DiStefano, Christine, Min Zhu and Diana Mindrila (2009) "Understanding and using factor scores: Considerations for the applied researcher". Practical Assessment, Research \& Evaluation 14 (20) 1-11.

Dudal, Paul and Geert Deloof (2004). Vrij Centrum Voor Leerlingenbegeleiding. Leerlingenvolgsysteem. Wiskunde: Toetsen 5 - Basisboek. Antwerpen: Garant.

Erikson, Robert, John H. Goldthorpe and Lucienne Portocarero (1979). "Intergenerational Class Mobility in 3 Western European Societies - England, France and Sweden". British Journal of Sociology 30 (4): 415-441.

Esterberg, Kristin G. (2002). Qualitative Methods in Social Research. Boston: McGraw-Hill.

Fielding, Nigel (1993). "Qualitative Interviewing”. Researching Social Life. Ed. G. N. Gilbert. London: Sage. 130-145.

Goodenow, Carol (1993). "The Psychological Sense of School Membership among Adolescents - Scale Development and Educational Correlates". Psychology in the Schools 30 (1): 79-90.

Han, Wen Jui (2012). "Bilingualism and Academic Achievement". Child Development 83 (1): 300-321. 
Helot, Christine and Andrea Young (2002). "Bilingualism and Language Education in French Primary Schools: Why and How Should Migrant Languages Be Valued?". International Journal of Bilingual Education and Bilingualism 5 (2): 96-112.

Jaspers, Jürgen (2008). "Problematizing Ethnolects: Naming Linguistic Practices in an Antwerp Secondary School”. International Journal of Bilingualism 12 (1-2): 85-103.

Johnson, Monika Kirkpatrick, Robert Crosnoe and Glen H. Elder (2001). "Students' Attachment and Academic Engagement: The Role of Race and Ethnicity". Sociology of Education 74 (4): 318-340.

Macedo, Donaldo (2000). "The Colonialism of the English Only Movement". Educational Researcher 29 (3): 15-24.

Maly, Ico (2012). N-Va. Analyse Van Een Politieke Ideologie. Berchem: EPO.

Mouw, Ted and Yu Xie (1999). "Bilingualism and the Academic Achievement of First- and Second-Generation Asian Americans: Accommodation with or without Assimilation?”. American Sociological Review 64 (2): 232-252.

OECD (2006). "Where Immigrant Students Succeed". A Comparative Review of Performance and Engagement in Pisa 2003. Paris: OECD.

Yagmur, Kutlay (2009). "Teaching the Mother Tongue in a Multilingual Europe”. Applied Linguistics 30 (2): 298-302.

, (2010). "An Evaluation of Turkish Language Teaching within the Context of Western European Language Policies”. bilig 55: 221-242.

Yagmur, Kutlay and Fons J. R. van de Vijver (2012). "Acculturation and Language Orientations of Turkish Immigrants in Australia, France, Germany, and the Netherlands". Journal of Cross-Cultural Psychology 43 (7): 1110-1130. 


\section{Belçika Okullarında Türkçe Konuşmak: Ög̃retmen Düşünceleri ve Asıl Sonuçları}

\section{Orhan Ag̃ırda g̃ \\ Kathelijne Jordens** \\ Mieke Van Houtte ${ }^{* * *}$}

Öz

Bu karma-yöntem araştırmanın konusu, Belçika'daki ilköğretim okullarında Türk göçmen çocuklarının Türkçe kullanımına ilişkin öğretmen düşüncelerini araştırmak ve bu öğretmen düşüncelerini anadili kullanımının getirdiği asıl sonuçlar ile karşılaştırmaktır. Nitel analizler Belçikalı öğretmenlerin Türkçe konuşulması hakkında çok olumsuz görüşlere sahip olduğunu ve anadili kullanımının öğrencilerin akademik başarıları için zararlı olduğuna inanıldığını ortaya koymuştur. Bu olumsuz öğretmen inançları sadece Belçika'daki asimilasyoncu politika bağlamında şekillenmemektedir; Belçikalı ögretmenlerin orta sınıf Türklerle etkileşimlerinin olumsuz düşünceleri güçlendirdiği görülmektedir. Bununla birlikte, 48 okulda 435 Türk öğrenciden derlenen veriler üzerinde yapılan nicel analizler sonucunda, evde veya okulda Türkçe konuşulmasının öğrencilerin akademik başarılarına hiçbir şekilde zarar getirmediği anlaşılmışır. Ancak, Türkçe konuşulması hakkındaki olumsuz okul kültürünün Türk öğrencilerinde reddedilme duygusunu uyandırdığı ve bu bağlamda okulda daha sık Türkçe konuşan öğrencilerin okula aidiyet duygusunu azaldığı ortaya çıkmışıır.

\section{Anahtar Kelimeler}

Dil kullanımı, akademik başarı, okula ait olma duygusu, Avrupalı Türkler, Belçika

\footnotetext{
Yrd. Doç. Dr., Amsterdam Üniversitesi, Çocuk Gelişimi ve Eğitimi Araşıırma Enstitüsü - Amsterdam / Hollanda orhan.agirdag@gmail.com

** Doktora Öğrencisi, Leuven Üniversitesi - Leuven / Belçika kathelijne.jordens@arts.kuleuven.be

**** Doç. Dr., Ghent Üniversitesi - Gent / Belçika mieke.vanhoutte@ugent.be
} 


\title{
Говорить на турецком в бельгийских школах: мнение учителя и фактические результаты
}

\author{
Орхан Агырдаг \\ Кателижне Джорденс ${ }^{* *}$ \\ Мике ван Хоут
}

\begin{abstract}
Аннотация
Предметом исследования данной работы, где использовались смешанные методы, является изучение мнения бельгийских учителей начальной школы по поводу использования детей турецких иммигрантов турецкого языка в начальных школах Бельгии и сравнение этих мнений с фактическими результатами использования родного языка. Качественный анализ показал, что бельгийские учителя негативно относятся к использованию турецкого языка в школе и считают, что использование родного языка пагубно отражается на академической успеваемости учеников. Эти негативные убеждения учителей сформировались не только в контексте ассимиляционной политики Бельгии; наблюдается, что взаимодействие бельгийских учителей с учениками турками средней школы усиливает негативные мысли учителей. Тем не менее, количественный анализ данных 435 турецких учеников в 48 школах показал, что использование дома или в школе турецкого языка не оказало никакого негативного влияния на академическую успеваемость учеников. Однако, негативное отношение к турецкому языку в школе вызывает чувство отторжения у учеников и в этом контексте у учеников, часто говорящих на турецком языке, снижается чувство принадлежности к данной школе.
\end{abstract}

\section{Ключевые слова}

использование языка, академическая успеваемость, чувство принадлежности к школе, европейские турки, Бельгия

\footnotetext{
* И.о.доц. док. Амстердамский университет, научно-исследовательский институт детского развития и образования / Нидерланды orhan.agirdag@gmail.com

** Док. Лёвенский университет / Бельгия kathelijne.jordens@arts.kuleuven.be

**** Доц.док.Гентский университет / Бельгия mieke.vanhoutte@ugent.be
} 